\title{
KORUPSI YANG DILAKUKAN ANGGOTA DPRD DALAM PENDEKATAN HUKUM ISLAM
}

\author{
Dwi Ari Kurniawati \\ Fakultas Agama Islam Universitas Islam Malang \\ Email: dwiaribhakti@gmail.com
}

\begin{abstract}
Based on the description above, the corruption committed by some members of the Regional Representatives Council (DPRD) is no different from corruption by other parties. Means of corruption, including acts violating judicial norms. In Islamic studies, corruption is an act which is forbidden in Islam the legal position is haram. Keharamannya can be searched or arguments based on the teachings of Islam as risywah (bribes), saraqah (theft), al-gasysy (fraud), and khiyanah (betrayal).
\end{abstract}

Keywords: corruption, Islamic law, the Regional Representatives Council (DPRD)

\section{PENDAHULUAN}

Bangsa manapun di muka bumi mengakui kalau korupsi itu merupakan salah satu jenis kejahatan atau tindak pidana yang serius, suatu kejahatan yang berkategori istimewa (exstra Haryadi, 2012). Yang jelas-jelas dampak negatif sangat serius. Sayangnya, korupsi ini tidak sulit ditemukan di setiap rezim ke rezim, bangsa ke bangsa atau negara manapun. (Sofyan Maulana, 2011)

Kongres PBB ke 8/1990 di Havana dalam laporannya menyatakan hakikat bahaya korupsi, yaitu dapat menghancurkan efektivitas potensial semua program pemerintah, dapat mengganggu/menghambat pembangunan dan menimbulkan korban individual dan kelompok. Sementara dalam Kongres PBB ke-9/1995 di Kairo disebutkan bahwa korupsi dapat membahayakan stabilitas dan keamanan masyarakat, merusak nilai-nilai demokrasi dan moralitas, dan membahayakan pembangunan sosial, ekonomi dan politik. (Haryadi, 2012).

Hasil dari UN Convention Against Corruption 2003 diantaranya menyatakan bahwa korupsi adalah ancaman bagi keamanan dan kestabilan masyarakat, merusak nilai-nilai moral dan keadilan, membahayakan "pembangunan yang berkelanjutan" dan "rule of lawa" dan mengancam stabilitas politik. Tidak jauh berbeda dengan hasil konvensi tersebut, Kongres PBB XI tahun 2005 juga menyatakan tentang hakikat bahaya korupsi, yaitu merintangi kemajuan sosial, ekonomi dan politik, sumber daya masyarakat dialokasikan tidak efisien, meningkatnya ketidakpercayaan terhadap lembaga-lembaga politik, produktivitas menurun, efisiensi administrative berkurang, merusak/mengurangi legitimasi politik dan mengganggu pembangunan ekonomi yang berakibat pada ketidakstabilan politik, lemahnya infrastruktur, sistem pendidikan dan kesehatan dan pelayanan sosial lainnya.

Pemerintahan Daerah yang baik (good local governance) merupakan isu yang paling mengemuka dalam pengelolaan administrasi publik dewasa ini di tengah maraknya kasus korupsi. Tuntutan gagasan yang dilakukan masyarakat 
kepada pemerintah penyelenggaraan pemerintahan daerah yang baik adalah sejalan dengan meningkatnya pengetahuan masyarakat di samping adanya globalisasi pergeseran paradigma pemerintahan dari "rulling government" yang terus bergerak menuju "good governance" dipahami sebagai suatu fenomena berdemokrasi secara adil. Untuk itu perlu untuk pelaksanaan memperkuat peran dan fungsi DPRD agar eksekutif dapat menjalankan tugasnya dengan baik. (A. Kartiwa, 2012)

\section{PEMBAHASAN}

\section{Korupsi yang dilakukan oleh sebagian anggota DPRD}

DPRD yang seharusnya mengontrol jalannya pemerintahan masyarakat, bukan sebaliknya merusak dan mengkondisikan Eksekutif untuk melakukan agar selalu sesuai dengan aspirasi penyimpangan-penyimpangan terhadap aturanaturan yang berlaku, melakukan kolusi dalam pembuatan anggaran agar menguntungkan dirinya, serta setiap kegiatan yang seharusnya digunakan untuk mengontrol eksekutif, justru sebaliknya digunakan sebagai kesempatan untuk "memeras" eksekutif sehingga eksekutif perhatiannya menjadi lebih terfokus untuk memanjakan anggota DPRD dibandingkan dengan masyarakat keseluruhan. Dengan demikian tidak aneh, apabila dalam beberapa waktu yang lalu beberapa anggota DPRD dari berbagai Kota/Kabupaten ataupun provinsi banyak yang menjadi tersangka atau terdakwa dalam berbagai kasus yang dindikasikan korupsi. Hal ini yang sangat disesalkan oleh semua pihak, perilaku kolektif anggota dewan yang menyimpang dan cenderung melanggar aturan-aturan hukum yang berlaku. (A. Kartiwa, 2012.)

Walaupun maraknya korupsi di DPRD ini secara kasat mata banyak diketahui masyarakat namun yang diadili dan ditindak lanjuti oleh aparat penegak hukum, sangatlah sedikit. Faktor ini dapat memicu ketidakpuasan masyarakat terhadap supremasi hukum di Negara kita. Elite politik yang seharusnya memberikan contoh dan teladan kepada masyarakat justru melakukan tindakantindakan yang tidak terpuji, memperkaya diri sendiri, dan bahkan melakukan pelanggaran hukum secara kolektif. Lemahnya penegakan hukum ini dapat memicu terjadinya korupsi secara kolektif oleh elite politik terutama anggota DPRD ini (A. Kartiwa, a 2012.). Kelemahan inilah yang membuat kepercayaan masyarakat terhadap peran-peran yang dilakukan DPRD berkurang. Masyarakat menilai, bahwa peran yang dilakukan oleh DPRD sekedar mencari keuntungan dibalik peran atau fungsi yang dijalankan, (Sofyan Mau lana, 2011)

Selama ini sudah berlaku pemahaman, bahwa sesungguhnya DPRD lebih berfungsi sebagai lembaga pengontrol terhadap kekuasaan pemerintah daerah daripada sebagai lembaga legislatif dalam arti yang sebenarnya. Namun dalam kenyataan sehari-hari, lembaga DPRD itu biasa disebut sebagai lembaga legislatif. Memang benar, seperti halnya pengaturan mengenai fungsi DPR- RI menurut 
ketentuan UUD 1945 sebelum diamandemen, lembaga perwakilan rakyat ini berhak mengajukan usul inisiatif perancangan produk hukum. (Wahyu Priyono, 2012).

Dewan Perwakilan Rakyat Daerah yang dibentuk di setiap propinsi dan kabupaten/kota pada umumnya dipahami sebagai lembaga yang menjalankan kekuasaan legilsatif, dan karena itu biasa disebut dengan lembaga legilsatif di daerah. Akan tetapi, sebenarnya fungsi legislatif di daerah, tidaklah sepenuhnya berada di tangan DPRD seperti fungsi DPR-RI dalam hubungannya dengan Presiden sebagaimana ditentukan dalam Pasal 20 ayat (1) juncto Pasal 5 ayat (1) UUD 1945 hasil Perubahan Pertama. Pasal 20 ayat (1) UUD 1945 menyeburkan bahwa DPR memegang kekuasaan membentuk UU, dan Pasal 5 ayat (1) menyatakan bahwa Presiden berhak mengajukan RUU kepada DPR. Sedangkan kewenangan untuk menetapkan Peraturan Daerah (Perda), baik daerah propinsi maupun kabupaten/kota, tetap berada di tangan Gubernur dan Bupati/Walikota dengan persetujuan DPRD. (Wahyu Priyono, 2012).

Pergeseran itu juga mengakibatkan terjadinya perubahan dalam pola berperilaku secara individual maupun kolektif (kelompok). Sayangnya perubahan ini bukannya memberikan kontribusi positip bagi kehidupan masyarakat dan negara, melainkan justru mengakibatkan banyaknya muncul problem baru, yang polanya lebih buruk dibandingkan sebelum terjadinya pergeseran kekuasaan itu. Pola berelasi politik yang membawa perubahan bermakna (bermanfaat) bagi kehidupan masyarakat tidak dimasukkan sebagai substansinya. Sikap-sikap yang ditunjukkan dan pola perilaku yang dibangun oleh unsur rezim baru tidak lebih cacat moral dibandingkan sebelumnya. Rasa optimisme terhadap terjadinya pembaharuan di tengah masyarakat semakin jauh dari harapan akibat perilaku unsur elit yang bertolak belakang dengan aspirasi masvarakat.

Dimensi negatif yang menjadi dampaknya perilaku politisi itu kemudian tercatat, misalnya adanya julukan publik kalau komunitas elit politik Indonesia belum berhasil menunjukkan keteladanan sebagai manusia-manusia utama dalam kinerja yang berbasis moralitas dan norma-norma lain yang dibenarkan, sebaliknya mereka telah terjerumus dalam perilaku-perilaku yang menyimpang dari panduan perilaku (code of conduct) yang sudah dibuatnya sendiri. Panduan berperilaku yang dibuatnya ini adalah kode etik Dewan Perwakilan Rakyat Daerah (DPRD). Kode etik berperilaku ini merupakan kumpulan norma yang digunakan oleh organisasi dan masyarakat untuk menilai sikap dan perilaku Dewan Perwakilan Rakyat Daerah (DPRD). Peran kode etik ini juga ikut menentukan 5 potret negara hukum, karena dalam kode etik ini terumus norma yang mengatur perilaku Dewan Perwakilan Rakyat Daerah (DPRD). (Fran Magnis Suseno, 1994)

Masyarakat sekarang tergolong masyarakat kritis terhadap perkembangan yang terjadi di sekitarnya, terutama di dunia politik. Perilaku elit politik dijadikan sebagai obyek penilaian. Perilaku Dewan Perwakilan Rakyat Daerah (DPRD) 
misalnya termasuk yang tidak lepas dari opini publik, karena mereka selain menjadi representasi suara rakyat atau perwujudan kekuatan rakyat melalui produk pesta demokrasi (Pemilu), mereka juga tergolong komunitas elit yang peran-perannya telah atau sedang menjadi obyek penilaian dan gugatan, diantaranya menyangkut pola kerjanya yang bermisikan memperjuangkan aspirasi rakyat, produktifitasnya di bidang pembaharuan hukum nasional, serta pola kemitraan yang dibangunnya dengan eksekutif dalam menjalankan roda pemerintahan baik di tingkat pusat maupun daerah. Pola kemitraan yang dibangun antara legislatif (DPRD) dengan eksekutif diposisikan sebagai sumber problem sosial-politik yang selama ini terjadi.

Dalam hubungannya dengan eksekutif itulah yang kemudian menempatkan Dewan Perwakilan Rakyat Daerah (DPRD) mendapatkan banyak stigma buruk sebagai komunitas elit strategis yang berada di lingkaran penyelenggaraan manajemen pemerintahan yang tidak mewakili rakyat, tetapi mewakili kepentingan dan obsesi dirinya sendiri, golongan, keluarga, dan partai politiknya, dan bahkan tidak sedikit diantaranya yang jadi tersangka kasus-kasus bertemakan KKN (Korupsi, Kolusi, dan Nepotisme).

Bangunan pemerintahan tidak lagi menjadi potret pemerintahan yang bersih (clean government) akibat perilaku kemitraan yang disalahgunakan atau disalah-fungsikan dalam implementasinya Pemerintahan di daerah pun seringkali terkena masalah hukum akibat pola kemitraan yang salah dalam penerpannya. atau pelaksanaannya.

Problem besar dalam kehidupan kenegaraan maraknya kasus dapat terjadi akibat penyalahgunaan memberdayakan demokrasi, gagalnya menjaga tegaknya hak-hak asasi manusia, meminggirkan atau menodai citra diri negara sebagai negara hukum, dan membuka ruang gelap tampilnya kekuatan politik dalam mendahulukan absolutisme, totalitarianisme, diktatorianisme, dan anarkisme, serta kultur korupsi dimana-mana. (Misbahul Munir, 2004)

Korupsi sangat berbahaya bagi sosial ekonomi masyarakat. Korupsi di bidang pendidikan misalnya, akan menghambat siswa belajar karena keterbatasan sarana dan prasarana. Uang 6,7 trilyun dalam kasus Century setidaknya dapat diberikan sebagai beasiswa sebanyak 1 juta rupiah kepada 6.700 .000 siswa. Dengan melihat multi effect dari korupsi di atas, sangatlah wajar jika korupsi dikategorikan sebagai extra ordinary crime dengan berbagai dimensinya, seperti economic crime, organized crime, white collar crime dan political crime. Dengan bentuknya yang extra ordinary crime, maka upaya pencegahan dan pemberantasan korupsi harus ditempuh dengan cara-cara yang luar biasa pula. Jika bisa sesempurna mungkin sehingga tidak ada lagi celah bagi para koruptor untuk bebas, terlebih jika ada niat ingin melemahkan atau membubarkan KPK. (Dwi Haryadi, 2012) 


\section{Perspektif Hukum Islam}

Istilah korupsi bukanlah merupakan istilah yang berasal dari bahasa Arab yang adalah merupakan bahasa al-Quran dan Al-Hadis yang adalah merupakan sumber utama hukum Islam. Namun demikian di dalam al-Quran terdapat istilahistilah yang pengertian dan unsurnya terkandung di dalam pengertian korupsi. Istilah-istilah tersebut adalah Risywah yang artinya suap, Saragah yang artinya Pencurian, al-Gasysy ataupun al-Ghulul yang artinya Penipuan, dan Khiyanah yang artinya Penghianatan. Keempat istilah ini adalah merupakan 25 an bahasa moral dan kemanusiaan yang secara tegas terkandung dalam al-Quran dan al-Hadis Rasulullah SAW (Ahmad Supardi Hasibuan, 2013).

Secara teoritis kedudukan korupsi dalam hukum Islam adalah merupakan tindakan kriminal yang dalam istilah Islam disebut dengan Jinayah dan atau Jarimah. Asas legalitas hukum Islam, tentang korupsi sangatlah jelas dan tegas. Ia merupakan suatu tindakan pencurian dan karenanya pelaku korupsi haruslah dihukum (Ahmad Supardi Hasibuan, 2013). Korupsi ini merupakan jenis kejahatan yang telah terbukti menghancurkn sendi- sendi kehidupan berbangsa. Banyak sudah sumberdaya bangsa yang dikorupsi, yang membuat rakyat kehilangan hak kesejahteraan hidupnya (Idam Khalid, 2011)

Di dalam al-Quran Allah SWT berfirman: dan janganlah sebahagian kamu memakan harta sebahagian yang lain di antara kamu dengan jalan yang bathil dan (janganlah) kamu membawa (urusan) harta itu kepada hakim, supaya kamu dapat memakan sebahagian daripada harta benda orang lain itu dengan (jalan berbuat) dosa, padahal kamu mengetahui.

Dari ayat tersebut di atas dapatlah kita pahami bahwa Allah SWT sangat melarang hambanya untuk mengambil dan memakan harta yang diperoleh dari jalan yang tidak benar. Selain itu, ayat tersebut juga bermakna bahwa Allah SWT membenci dan melarang hambaNya untuk menguasai harta orang lain tanpa melalui cara-cara yang benar. Perlindungan terhadap harta adalah merupakan salah satu pokok pertimbangan dalam menetapkan hukum Islam yang terkenal dengan Asasul Khomsah (prinsip-prinsip yang lima) yaitu memelihara agama, memelihara jiwa, memelihara akal, memelihara keturunan/kehormatan dan memelihara harta. Perlindungan yang digariskan ag hukum Islam merupakan perlindungan yang berorientasi menjaga martabat manusia dan bangsa dari kehancuran. Koruptor terbukti dari waktu ke waktu telah menjadikan kekayaan bangsa salah alamat dalam penggunaannya statusnya menjadi kekayaan pribadi. (Ahmad Supardi Hasibuan, 2013, Idam Khalid, 2011)

Selain itu korupsi adalah salah satu bentuk pengkhianatan terhadap agama sebab ia mengkianati amanah yang dibebankan di pundaknya. Ia juga menyelewengkan dan menyalahgunakan tugas dan tanggungjawab yang diberikan kepadanya. Oleh karena itu ia harus dihukum dan diberikan sanksi hukum yang jelas dan berat sebab dalam hal ini ada dua dosa yang dia pikul. Pertama adalah 
dosa kepada bangsa dan negara sebab dia menyalahgunakan keuangan dan perekonomian negara, dan kedua adalah dosa kepada Allah SWT sebab dia mengkhianati amanah yang dibebankan kepadanya. Di Dalam al-Quran Allah SWT berfirman: Sesungguhnya Allah menyuruh kamu menyampaikan amanat kepada yang berhak menerimanya, dan (menyuruh kamu) apabila menetakan hukum di antara manusia supaya kamu menetapkan dengan adil. Sesungguhnya Allah memberi pengajaran yang b sebaik-baiknya kepadamu. Sesungguhnya Allah adalah Maha Mendengar lagi Maha Melihat.

Di dalam ayat lain disebutkan: hai orang- orang yang beriman, jangan lah kamu mengkhianati Allah dan Rasul (Muhammad) dan (juga) janganlah kamu mengkhianati amanat-amanat yang dipercayakan kepadamu, sedang kamu mengetahui.

Di dalam salah satu Hadis Rasulullah SAW bersabda: laksanakanlah amanah kepada orang yang memberikannya kepadamu dan janganlah kamu melakukan pengkhianatan (sekalipun) terhadap orang yang pernah mengkhianatimu. Di dalam hadis lain juga disebutkan: tidak sempurna iman seseorang yang tidak amanah dan tidak sempurna agama seseorang yang tidak menunaikan janji.

Korupsi dalam pandangan agama Islam dapat juga dimasukkan dalam kategori al-Gosysy dan atau al-Ghulul (penipuan), sebab korupsi termasuk dalam kategori menipu orang banyak ataupun menipu negara untuk kepentingan peribadinya. Di dalam salah satu hadis, Rasulullah SAW bersabda: siapa yang menipu, maka dia tidak termasuk ummatKu. Pada hadis lain disebutkan: tidak diterima sholat seseorang kecuali dalam keadaan suci dan tidak sah sedekah seseorang yang bersumber dari penipuan (Ahmad Supardi Hasibuan, 2013)

Selain hal tersebut di atas, korupsi sangat dekat dengan istilah risywah (suap menyuap) dalam ajaran agama Islam, sebab korupsi itu salah satu bentuknya adalah melakukan penyuapan atas seseorang dengan imbalan tertentu untuk mendapatkan jabatan tertentu pula. Masalah suap menyuap ini mendapat perhatian yang sangat serius dari Rasulullah SAW, sehingga banyak sekali hadishadis yang disampaikan oleh Rasulullah SAW berkaitan dengan suap menyuap (risywah). (Ahmad Supardi Hasibuan, 2013)

Di dalam salah satu hadis, Rasulullah SAW bersabda: dari Abdullah ibnu Amar berkata Rasulullah SAW melaknat orang yang menyuap dan penerima suap. Al-Khatibi Rahimahullohu dalam Syarh Sunan Abu Daud yang berjudul Maalim AsSunan berkata, ar-rosyi adalah orang yang memberikan suap dan al-Murtasyi adalah orang yang menerima suap. Keduanya diberi hukuman kalau mereka benar terlibat dalam persekongkolan uap menyuap dengan maksud bathil dari orang yang menyuap, dan memberikannya pada orang yang menerima dengan cara yang tidak benar pula. Tapi jika memberikannya pada orang yang berhak, atau memberi untuk menebus dirinya dari suatu kezaliman, maka hal itu tidak dilarang. 
Atas dasar penjelasan-penjelasan tersebut di atas, dan menghubungkannya dengan sumber-sumber hukum Islam, baik yang tertuang dalam al-Quran maupun dalam al-Hadis, maka dapat disimpulkan bahwa korupsi hukumnya adalah haram. Keharamannya ini bersifat mutlak dan tidak dapat ditawar-tawar lagi, apalagi di dalamya terdapat dua dosa sekaligus yaitu pertama, dosa kepada bangsa dan negara dan yang kedua dosa kepada Allah SWT. (Ahmad Supardi Hasibuan. 2013)

Memberantas korupsi bukanlah pekerjaan yang mudah, apalagi di bumi Indonesia tercinta ini sebab praktek korupsi sudah menjadi semacam wabah penyakit yang senantiasa menggerogoti tubuh manusia dan terjadi pada semua lini dan sektor kehidupan berbangsa dan bernegara. Oleh karena itulah maka tidak salah apabila ada yang mengatakan bahwa korupsi sudah menjadi bahagian dari budaya bangsa Indonesia. Dengan demikian maka untuk mencegah dan memberantasnyapun bukanlah merupakan pekerjaan mudah bagaikan membalik telapak tangan, akan tetapi diperlukan keseriusan, keterpaduan dan komitmen dari pemerintah dan aparat penegak hukum dan bila perlu bangsa Indonesia harus menyatakan perang terhadap korupsi, sebab tanpa ini maka mustahil korupsi dapat dibasmi dibumi nusantara.

Ahmad Supardi Hasibuan (2013) berpendapat, bahwa adapun cara-cara yang dapat ditempuh untuk memberantas korupsi adalah sebagai berikut:

Pertama, meningkatkan penghayatan ajaran agama. Meningkatkan pengetahuan, pengamalan dan penghayatan ajaran agama kepada para pemeluknya, sehingga ummat beragama dapat menangkap intisari daripada ajaran agama itu dan dampak positif dari ajaran agama itu dapat diresapi hingga melekat pada tindak tanduk serta perilaku masyarakat. Dengan demikian maka ibadah yang dilakukan oleh seseorang bukan hanya bersifat ritual ceremonial belaka, akan tetapi ibadah itu dilaksanakan bersifat ritual aktual.

Kedua, meluruskan pemahaman keagamaan Meluruskan pemahaman keagamaan yang dimaksudkan di sini adalah meluruskan pemahaman keagamaan bahwa memberikan sesuatu infaq/shodaqah kepada siapa sajapun itu akan mendapatkan pahala manakala uang ataupun harta yang diinfakkan/disedekahkan itu berasal dari yang halal dan bukan berasal dari yang haram. Apabila uang/harta itu berasal dari yang halal maka barulah satu kebaikan mendapatkan pahala tujuh ratus kali lipat, sebagaimana tercermin dalam Firman Allah SWT: perumpamaan (nafkah yang dikeluarkan oleh) orang-orang hartanya di Jalan Allah adalah serupa dengan sebutir benih yang menumbuhkan tujuh butir, pada tiap-tiap butir seratus biji. Allah melipat gandakan (ganjaran) bagi siapa yang Dia kehendaki. Dan Allah Maha luas (kurniaNya) lagi Maha Mengetahui.

Apabila sebaliknya (berasal dari haram) maka infaq/shodaqahnya itu tidak akan mendapatkan ganjaran apa-apa kecuali ganjaran kejahatan/dosa, sebagaimana hadis Nabi SAW: tidak diterima sholat seseorang kecuali dalam 
keadaan suci dan tidak diterima sedekah seseorang yang yang menafkahkan am oti na an yang la bersumber dari penipuan.

Ketiga, merubah sistem. Kalau seseorang melakukan tindak pidana korupsi salah satunya adalah disebabkan adanya kesempatan dan peluang yang didukung oleh sistem yang sangat kondusif untuk berbuat korupsi, maka sistem itu harus dirubah dan diperbaiki sehingga setiap orang tidak mempunyai kesempatan dan peluang untuk berbuat korupsi. Salah satu bentuk yang harus diperbaiki adalah adanya pengawasan melekat dari atasannya, tidak adanya uang pelicin, uang setoran dan lain.

Keempat, Meningkatkan Mentalitas. Merubah dan meningkatkan mentalitas bangsa Indonesia dari mentalitas yang rapuh menjadi mentalitas yang kuat dan tahan banting. Untuk meningkatkan mentalitas ini dapat dilakukan melalui peningkatan pengetahuan dan pengamalan agama, sebab apabila pengetahuan dan pengamalan agama seseorang baik, maka dapat dipastikan bahwa sikap mental orang tersebut akan baik, namun demikian tidak semua yang bermental baik berarti memiliki pengetahuan dan pengamalan agama yang baik, sebab masih banyak penyebab-penyebab lainnya yang menyebabkan seseorang bermental baik.

Kelima, meningkatkan penghasilan. Meningkatkan perekonomian dan atau gaji pegawai sesuai dengan kebutuhan hidup di masyarakat adalah merupakan salah satu langkah penting yang harus dilakukan dalam rangka menghilangkan perilaku korupsi sebab harus diakui bahwa gaji pegawai saat ini tidak mencukupi untuk hidup layak. Gaji yang diterima itu hanya cukup untuk satu atau dua minggu, makanya para pegawai berusaha untuk mendapatkan tambahan yang salah satunya melalui korupsi. Gaji pegawai ini seharusnya diberikan sampai dia bisa mampu menyekolahkan anaknya dan juga bisa menyimpan/menabung untuk keperluan hari tuanya. Dan bahkan pegawai negeri itu harus diberikan gaji sehingga dia bisa hidup layak sebagaimana yang lainnya dengan fasilitas yang memadai.

Keenam, merubah budaya yang mendorong korupsi. Merupakan sebuah kebiasaan bagi kita orang Indonesia bahwa setiap seseorang menjadi pejabat tinggi dalam sebuah pemerintahan, maka yang bersangkutan akan menjadi sandaran dan tempat bergantung bagi keluarganya, akibatnya dia diharuskan melakukan perbuatan korupsi untuk memenuhi kebutuhan-kebutuhan keluarganya tersebut, apalagi permintaan akan kebutuhan itu datang dari orang yang sangat berpengaruh bagi dirinya seperti mamak umpamanya. Selain daripada itu dalam budaya kita akan dianggap bodoh seseorang manakala dia tidak mempunyai apa-apa di luar penghasilannya, sementara dia menduduki suatu jabatan penting, akibatnya dipaksa untuk melakukan korupsi. Budaya ini harus dirubah dan dijadikan menjadi keluarga akan merasa malu manakala seseorang dari keluarganya membantu keluarga yang lainnya dengan uang hasil korupsi sekalipun dia pejabat tinggi. Oleh karena itu maka apa yang bersangkutan lebih 
baik tidak membantu keluarganya, kalau uang bantuan itu berasal dari ber hasil korupsi.

Ketujuh, menghilangkan kebiasaan dan kebersamaan. Menghilangkan kebiasaan dan kebersamaan dalam melakukan korupsi, sebab dalam kenyataannya Praktek korupsi sudah menjadi sebuah kebiasaan bagi yang mempunyai peluang dan kesempatan melakukannya, ditambah lagi praktek korupsi ini telah dilakukan oleh banyak orang, dan bahkan dilakukan secara berjamaah. Untuk itu maka kebiasaan ini harus dicegah dan dibasmi sampai ke akar-akarnya, sehingga hilang sama sekali dari bumi Indonesia.

Kedelapan, meningkatkan penegakan hukum. Penegakan hukum kita memang sangat lemah padahal aturan-aturannya sudah lengkap, makanya orang tidak kapok melakukan korupsi secara berulang-ulang. Oleh karena itu maka penegakan hukum ini harus dilaksanakan tanpa pandang bulu dan tanpa pilih kasih dengan hukuman yang berat dan tegas sebagaimana yang disebutkan oleh Nabi Muhammad SAW, : Sekiranya anakKu Fatimah mencuri maka pasti akan saya potong tangannya. Penegakan hukum ini dapat juga dilakukan oleh masyarakat dengan cara mengasingkan atau memboikot si koruptor dari pergaulan umum sebagai contoh, apabila si koruptor mengundang untuk menghadiri pesta pernikahan anaknya umpamanya, maka masyarakat bersepakat untuk tidak menghadiri pestanya. Atau dapat juga dalam bentuk tidak melibatkannya dalam kegiatan-kegiatan sosial kemasyarakatan. Dan apabila dipandang perlu dapat juga dilakukan dengan memboikat si koruptor dari jual beli kebutuhan sehari-hari. Bila dia menjual sesuatu maka tidak dibeli jualannya dan bila dia hendak membeli sesuatu maka tidak dijual padanya.

Kesembilan, menumbuhkan rasa bersalah dan rasa malu. Hal ini dirasakan sangat penting sebab para koruptor dan sebahagian penduduk bangsa Indonesia telah hilang rasa bersalah dan apalagi rasa malunya. Oleh karena itu maka perlu dilakukan upaya-upaya untuk menumbuhkan rasa bersalah dan rasa malu ini. Hal ini dapat dilakukan dengan pendekatan agama.

Kesepuluh, menumbuhkan sifat kejujuran dalam diri. Hal ini dirasakan sangat urgent sebab kejujuran adalah merupakan satu asset yang sangat berharga bagi seseorang yang beriman dan bertaqwa kepada Allah SWT, sebab kejujuran akan mampu menjadi benteng bagi seseorang untuk menghindari perbuatanperbuatan munkar seperti perbuatan korupsi ini. Oleh karena itulah maka sejak kecil hu dalam rumah tangga kejujuran sudah harus ditanamkan kepada anakanak, begitu juga di sekolah-sekolah, pembinaan dan penerapan sifat kejujuran haruslah mendapat prioritas utama dari para guru dan ibu guru.

Kesebelas, menghilangkan sikap tamak dan serakah. Menghilangkan Sikap tamak dan serakah adalah merupakan hal yang sangat penting dalam pemberantasan korupsi sebab kedua sifat ini menjerumuskan ummat manusia ke jurang kehinaan dan kehancuran sebab kedua sikap ini mengantar manusia 
kepada sikap tidak pernah merasa puas dan tidak pernah merasa cukup sekalipun harta yang telah dimilikinya sudah melimpah ruah. Hal ini antara lain dapat dilakukan dengan pendalaman, pengamalan dan penghayatan ajaran agama.

Keduabelas, menumbuhkan budaya kerja keras. Menumbuhkan budaya kerja keras haruslah dijadikan menjadi prioritas utama dalam pencegahan korupsi sebab sikap ini akan dapat membentengi orang dari sifat ingin cepat kaya, tanpa usaha dan tanpa kerja keras. Dalam ajaran agama disebutkan bahwa bekerja adalah merupakan suatu kewajiban yang harus dilakukan oleh ummat.

Ketigabelas, menghilangkan sifat materialistik, kapitalistik dan hedonistik, Ketiga sifat ini sangat rentan menjerumuskan seseorang untuk terjerumus dalam melakukan perilaku korupsi. Orang yang memiliki ketiga sifat ini tidak akan pernah merasa puas dan cukup dalam hal harta, selalu kehausan dan kekurangan setiap saat. Oleh karena itulah maka ketiga sifat ini harus dikikis habis dari penduduk negeri ini.

\section{KESIMPULAN}

Berdasarkan uraian diatas, maka korupsi yang dilakukan oleh sebagian anggota DPRD adalah tidak berbeda dengan korupsi yang dilakukan oleh pihakpihak lain. Artinya korupsinya termasuk perbuatan melanggar norma-norma yuridis. Dalam kajian Islam, korupsi ini merupakan perbuatan yang dilarang dalam ajaran agama Islam yang kedudukan hukumnya adalah haram. Keharamannya ini bisa dicari atau berlandaskan dalil-dalil dalam ajaran agama Islam seperti risywah (suap), saraqah (pencurian), al-gasysy (penipuan), dan khiyanah (penghianatan).

Korupsi yang dilakukan oleh sebagian anggota DPRD menimbulkan dampak negatif yang sangat besar bagi suatu bangsa dan Negara, sehingga pencegahan dan penanggulangannyapun harus dilakukan secara sungguh- sungguh dan terpadu antara seluruh komponen bangsa. Setiap komponen bangsa mempunyai kewajiban untuk menanggulangi korupsi, khususnya aparat penegak hukum yang berkewajiban menjadi penjerat atas segala bentuk tindak pidana korupsi.

\section{DAFTAR RUJUKAN}

A.Kartiwa, Implementasi Peran dan Fungsi DPRD dalam Rangka Mewujudkan "good governance", pustaka.unpad.ac.id/wp-ontent/uploads/ implementasi fungsi dprd.pdf,akses akses 10 Juni 2012. http:// 2009/05/ peran

Ahmad Supardi Hasibuan, Korupsi dan Pencegahannya Dalam Perspektif Hukum http://riau1.kemenag. go . id/ index.php?a=artikel\&id=327, akses 7 Mei Islam, 2013.

Dwi Haryadi, Bahaya Korupsi dan Integritas Penegak Hukum, http://www.ubb.ac.id/ ulen g kap php? j u dul= Baha y a\% 20korupsi\%20dan\%20integritas\% 20 pe negak\% $20 \mathrm{k} \mathrm{e} \mathrm{n} \mathrm{m} \mathrm{\&} \mathrm{i} \mathrm{h} \mathrm{m} \mathrm{u} \mathrm{\&}$ nomorurut_artikel=398, akses 11 Juni 2012. 
Franz Magnis Suseno, Etika Politik; Prinsip- k30 prinsip Moral Dasar Kenegaraan Modern, Gramedia Pustaka Utama, Jakarta, 1994.

Idam Khalid, Dampak Sistemik Korupsi di Indonesia, Pustaka Jaya, Jakarta, 2011.

Misbahul Munir, Pemilu, Demokrasi, dan ljtihad Politik Perempuan, Visipres, Surabaya,2004.

Wahyu Priyono, Optimalisasi Fungsi DPRD dalam Pengawas an Pemerintahon. Daerah, http://pekikdaerah.wordpress.com/ artikel-makalah/optimalisasifungs i-dprd- dalam-pengawas an-pemer intah-daerahl diakses 5 April 2012 